\title{
Is There A Favorable Cultural Profile For IFRS?: An Examination And Extension Of Gray's Accounting Value Hypotheses \\ David R. Borker, Manhattanville College, USA
}

\begin{abstract}
Gray (Gray, 1988) proposed a link between Geert Hofstede's (Hofstede, 1980) popular national culture dimensions used in comparative management analysis and his own comparative concepts for accounting. In the past twenty-four years, Gray's work has been cited by over 650 scholars. His article presented a hypothetical set of complex correspondences between Hofstede's original four dimensions of Power-distance, Individualism, Masculinity, and Uncertainty Avoidance and Gray's accounting values of Professionalism versus Statutory control, Uniformity versus Flexibility, Conservatism versus Optimism, and Secrecy versus Transparency. Gray's accounting dimensions were intended to capture underlying cultural values that would tend, in the absence of external influences or other factors, to influence a culture toward the development of certain types of accounting systems. The purpose of this paper is to identify which Gray values and which corresponding Hofstede cultural dimensions would be most supportive of the establishment of accounting standards like the International Financial Reporting Standards (IFRS), currently being adopted by nations throughout the world. A specific set or profile of Gray values most conducive to IFRS is identified and termed the IFRS-favorable profile. In arriving at this profile, the paper also addresses two newer Hofstede cultural dimensions, long-term orientation and Restraint versus Indulgence, and extends Gray's model by proposing how these two new Hofstede dimensions correspond to Gray's four accounting dimensions. The IFRS-favorable profile and the expansion of Gray's link to Hofstede are discussed as practical applications to facilitate successful IFRS implementation in individual countries.
\end{abstract}

Keywords: IFRS; Accounting and Culture; Gray; Hofstede; Cultural Profile; Gray’s Hypotheses

\section{INTRODUCTION}

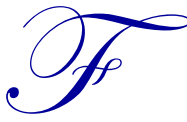

rom the start, International Financial Reporting Standards (IFRS) and the organization that created them, the International Accounting Standards Board (IASB), have been associated with the AngloAmerican accounting tradition and have emphasized the independence of accounting professionals and standard setting by independent accounting organizations. In Gray's summary of his four cultural accounting values and the accounting systems they foster, he identifies the Anglo countries out of all the world's cultural groups as being most closely associated with Professionalism and Flexibility in the sphere of "authority and enforcement," and Optimism and Transparency in the sphere of "measurement and disclosure" issues (Gray, 1988). Gray makes no mention of IFRS or IAS in his article since, at that time, these were merely one set of ideas among many, and not the world-wide phenomenon that they have become more recently.

This paper addresses the question of how the accounting value hypotheses developed by Gray, and derived from the Hofstede original four cultural dimensions, relate to the accounting values embodied in IFRS and proposes a specific IFRS-favorable profile based on the accounting value dimensions developed by Gray. The second objective of the paper is to expand the Gray model to include Hofstede's fifth and sixth cultural dimensions, developed subsequent to Gray's article, and to include these dimensions in a proposed IFRS-favorable profile. 
In the ascent of IFRS as the world standard for international financial reporting, it is important to describe, with as much precision as possible, the relationship between Gray's classification of accounting values and accounting cultures and the accounting values embodied in IFRS. Many critics identify IFRS as representing a "western" Anglo-American tradition associated with the expansion of capitalism and multinational corporations. These values may be foreign or irrelevant to other national cultures, especially those of developing countries. Gray's cultural accounting values provide a basis for identifying accounting profiles that favor IFRS-like accounting systems, as well as, profiles that do not. Gray himself expressed a position of neutrality toward the world's various accounting systems and their disparate underlying values. The legacy of the Gray model provides a useful framework from which to evaluate opportunities and challenges faced by countries with diverse cultural values that choose IFRS adoption as a link to the global economy. Providing an explicit determination of an IFRS-favorable profile from the Gray accounting values, and expanding his original hypotheses to include the two subsequent Hofstede cultural dimensions, contribute to this effort.

\section{HOFSTEDE AND GRAY: THE STUDY OF ACCOUNTING AND CULTURE}

\section{Accounting and Culture Prior to Gray}

Prior to Gray's study, no research focused explicitly on the relationship between culture and accounting systems and practices. Prior research on international accounting differences considered the effects of a broad range of environmental factors on the development of accounting systems and on structural patterns that could be used to classify the different accounting systems (Mueller, 1967; Zeff, 1971; Radebaugh L. H., 1975; Nair \& Frank, 1980; Nobes, 1983). The nature of these studies is discussed extensively in Gray’s classic work (Gray, 1988).

\section{Hofstede's Cultural Dimensions}

In his early research, Hofstede (Hofstede, 1980) identified four measurable dimensions that differentiate cultures. The data upon which these dimensions were initially developed came from survey results collected within one large multinational business organization (IBM) in 72 countries. Subsequent surveys had a more diverse base. (Hofstede, Hofstede, \& Minkov, 2010) The original four dimensions are:

1. Individualism versus Collectivism (IDV) - The fundamental issue addressed by this dimension is the degree of interdependence a society maintains among its members. It has to do with whether people's selfimage is defined in terms of ' $I$ ' or ' $W$ e.' In individualist societies, people are supposed to look after themselves and their direct family only. In collectivist societies, people belong to 'in groups' that care for them in exchange for loyalty.

2. Power Distance (PDI) - This dimension deals with the fact that all individuals in societies are not equal. It expresses the attitude of the culture towards these inequalities among us. Power Distance is defined as the extent to which the less powerful members of institutions and organizations within a country expect and accept that power is distributed unequally.

3. Masculinity versus Femininity (MAS) - A high or masculine score on this dimension indicates that a society is driven by competition, achievement and success, with success being defined by the winner/best in field - a value system that starts in school and continues throughout organizational behavior. A feminine score on this dimension indicates that the dominant values in society are caring for others and quality of life. A feminine society is one in which quality of life is the sign of success. Standing out from the crowd is not admirable. The fundamental issue here is what motivates people - wanting to be the best (masculine) or liking what you do (feminine).

4. Uncertainty Avoidance (UAI) - This dimension deals with the way a society considers the fact that the future can never be known, i.e., should we try to control it or just let it happen? This ambiguity brings with it anxiety, and different cultures have developed ways to deal with this anxiety. The extent to which the members of a culture feel threatened by ambiguous/unknown situations and have created beliefs and institutions that avoid these is reflected in the UAI score (Hofstede, Hofstede, \& Minkov, 2010). 
Subsequently, two additional cultural dimensions were established by Hofstede and his associates. (Hofstede, Hofstede, \& Minkov, 2010):

1. Long-Term Orientation versus Short-Term Orientation (LTO) - The Long-Term Orientation dimension is closely related to the teachings of Confucius and can be interpreted as dealing with society's search for virtue; i.e., the extent to which a society shows a pragmatic future-oriented perspective rather than a conventional historical short-term point of view.

2. Indulgence versus Restraint (IVR) The Indulgence versus Restraint dimension consists of two poles. Indulgence stands for an inclination to allow relatively free gratification of basic and natural human desires related to enjoying life and having fun. Restraint, the opposite pole, reflects a conviction that such gratification needs to be curbed and regulated by strict norms.

\section{The Gray Accounting Value Dimensions}

Gray constructed a set of four accounting value dimensions that he derived from the original four Hofstede cultural dimensions (Gray, 1988):

1. Professionalism versus Statutory Control refers to professional judgment and self-regulation in contrast to compliance with rigid legal requirements and legislative control.

2. Uniformity versus Flexibility indicates the level of enforcement of standardized and consistent accounting practices.

3. Conservatism versus Optimism indicates a vigilant approach to accounting measurement, as opposed to a more optimistic and risk-taking approach.

4. Secrecy versus transparency refers to confidentiality and the constraint of disclosure of information, as opposed to a more transparent and publicly accountable approach.

The relationships between the four accounting value dimension and the Hofstede four cultural dimensions are shown in Table 1 and defined in the four hypotheses proposed by Gray (Gray, 1988).

Table 1: Gray's Four Hypotheses

\begin{tabular}{|l|l|}
\hline H1 & $\begin{array}{l}\text { The higher a country ranks in terms of individualism and the lower it ranks in terms of uncertainty avoidance and power } \\
\text { distance then the more likely it is to rank highly in terms of professionalism. }\end{array}$ \\
\hline H2 & $\begin{array}{l}\text { The higher a country ranks in terms of uncertainty avoidance and power distance and the lower it ranks in terms of } \\
\text { individualism then the more likely it is to rank highly in terms of uniformity. }\end{array}$ \\
\hline H3 & $\begin{array}{l}\text { The higher a country ranks in terms of uncertainty avoidance and the lower it ranks in terms of individualism and } \\
\text { masculinity then the more likely it is to rank highly in terms of conservatism. }\end{array}$ \\
\hline H4 & $\begin{array}{l}\text { The higher a country ranks in terms of uncertainty avoidance and power distance and the lower it ranks in terms of } \\
\text { individualism and masculinity then the more likely it is to rank highly in terms of secrecy. }\end{array}$ \\
\hline
\end{tabular}

Gray fine-tuned the above hypotheses to reflect his judgment that for some of his accounting value dimensions, the linkages to Hofstede's four cultural dimensions were not equally strong. For example, in the case of Conservatism, Gray noted a strong linkage with Uncertainty Avoidance (UAI), but much weaker linkages to the other three dimensions; i.e., PDI, IDV, and MAS. For the Gray values Uniformity and Professionalism, the Hofstede Power Distance dimension shows a weaker linkage that the other cultural dimensions that have a determined relationship. Finally, for Gray's Secrecy versus Transparency accounting value dimension, the Hofstede MAS shows a weaker linkage than any of the cultural dimensions that have a determined relationship. The above modifications made by Gray can be seen as extensions of his basic hypotheses on the relationship between his accounting value constructs and the Hofstede cultural dimensions (Gray, 1988). 


\section{ANALYSIS OF GRAY'S HYPOTHESES AND THE ROLE OF THE ANGLO-AMERICAN TRADITION}

\section{Gray Hypotheses Summarized As Positive And Negative Correspondences With The Hofstede Dimensions}

Baydoun and Willet summarized the relationships between each of Hofstede's cultural dimensions and Gray's accounting dimensions by using a plus sign (+) to indicate a "direct relationship" and a minus sign (-) to indicate an "inverse relationship." (Baydoun \& Willet, 1995) A question mark (?) was used to represent that "the nature of the relationship is indeterminate," as summarized in Table 2.

Table 2: Direct \& Inverse Relationships Between Gray's Accounting Dimensions \& Hofstede's Cultural Dimensions

\begin{tabular}{|l|c|c|c|c|}
\hline & Professionalism & Uniformity & Conservatism & Secrecy \\
\hline Power Distance (PDI) & - & + & $?$ & + \\
\hline Uncertainty Avoidance (UAI) & - & + & + & + \\
\hline Individualism (IDV) & + & - & - & - \\
\hline Masculinity (MAS) & $?$ & $?$ & - & - \\
\hline
\end{tabular}

Chanchani and MacGregor adapt Table 3, placing Gray's accounting values as rows and Hofstede's dimensions as columns, with all the notations remaining the same. (Chanchani \& MacGregor, 1999) This is shown in Table 3.

Table 3: Adapted Summary Of Relationships Between Gray's Accounting Dimensions \& Hofstede's Cultural Dimensions

\begin{tabular}{|l|c|c|c|c|c|}
\hline & $\begin{array}{c}\text { Power Distance: } \\
\text { PDI }\end{array}$ & $\begin{array}{c}\text { Individualism: } \\
\text { IDV }\end{array}$ & $\begin{array}{c}\text { Masculinity: } \\
\text { MAS }\end{array}$ & $\begin{array}{c}\text { Uncertainty } \\
\text { Avoidance: UAI }\end{array}$ & $\begin{array}{c}\text { Long-Term } \\
\text { Orientation: LTO }\end{array}$ \\
\hline Conservatism & + & - & - & + & + \\
\hline Uniformity & + & - & $?$ & + & + \\
\hline Professionalism & - & + & $?$ & - & - \\
\hline Secrecy & + & - & - & + & + \\
\hline
\end{tabular}

In addition to adopting a different layout, Chanchani and MacGregor insert additional relationship information on Hofstede's fifth cultural dimension - Long-Term Orientation (LTO). This new information is not explained or referenced in their article. It can be assumed to reflect the opinions of Chanchani and MacGregor as to how the Gray four accounting value dimensions relate to the Hofstede LTO dimension.

Borker (2012a, 2012b) has proposed a modification of the relationship notations in Table 1 to differentiate between relationships that Gray saw as strongly interrelated and those that he simply saw as having a relationship, as presented in Table 4.

Table 4: Hofstede-Gray Relationships For Hofstede's Original Four Dimensions With Modified Notations

\begin{tabular}{|l|c|c|c|c|}
\hline & $\begin{array}{c}\text { Power Distance: } \\
\text { PDI }\end{array}$ & $\begin{array}{c}\text { Individualism: } \\
\text { IDV }\end{array}$ & $\begin{array}{c}\text { Masculinity: } \\
\text { MAS }\end{array}$ & $\begin{array}{c}\text { Uncertainty } \\
\text { Avoidance: UAI }\end{array}$ \\
\hline Conservatism & + & - & - & ++ \\
\hline Uniformity & + & -- & $?$ & ++ \\
\hline Professionalism & - & ++ & $?$ & -- \\
\hline Secrecy & ++ & -- & - & ++ \\
\hline
\end{tabular}

In this table, pairings of Gray values and Hofstede dimensions that were cited by Gray as being significantly strong are so indicated by the use of a double plus sign $(++)$ or double minus sign $(--)$, depending on whether the strong relationship is "direct" or "inverse" (Gray, 1988). For example, in discussing Professionalism, Gray noted that Hofstede's IDV and UAI are strongly linked to his Professionalism value, while PDI is linked, but not as strongly to the Professionalism value. Gray also noted that Masculinity has no apparent linkage to Professionalism (Gray, 1988). All of these observations are reflected in Table 4 through the expanded notation. 


\section{Significance Of The Anglo-American Tradition In Gray's Concepts Of Accounting Cultures}

Gray made numerous references to the accounting practices and cultural orientation of the country grouping he refers to as the "Anglo" countries. The group is comprised of the United States (US), the United Kingdom (UK) and members of the British Commonwealth, including Canada, Australia, New Zealand and South Africa. These observations all suggest how Gray views the Anglo-American accounting cultures within each of his accounting value dimensions.

Regarding his Professionalism dimension, Gray indicates the long history of development of accounting professional organizations among the Anglo countries. With regard to the UK, he notes how results in the financial statements depend heavily on the judgment of the accountant as an independent professional. This independence is contrasted with the traditional position in France and Germany, where the accountant's role is concerned primarily with the implementation of relative prescriptive and detailed legal requirements (Gray, 1988).

With regard to the Uniformity dimension, ranging from strong Uniformity to Flexibility, the position of the Anglo-American group is equally clear. Gray contrasts France, where Uniformity operates for the imposition of tax rules and concern for national planning and macroeconomic goals, with the UK and US, where concern is with intertemporal consistency together with some degree of intercompany comparability subject to a perceived need for Flexibility (Gray, 1988).

On the Conservatism dimension, ranging from strong Conservatism to Optimism, Gray again juxtaposes Anglo-American countries with Continental European countries, noting the strongly conservative attitudes of France and Germany versus the much less conservative attitudes of accountants in the US and UK. Finally, for the Secrecy dimension, ranging from strong Secrecy to Transparency, Gray noted the lower levels of disclosure and instances of secret reserves evident in the Continental European countries as compared to the US and UK (Gray, 1988).

Gray summarized the relative position of the world's major accounting culture groups for his four accounting value dimensions in two graphs of intersecting axes forming quadrants in which he positioned labels for these groups, given their dimensional coordinates. Figure 1 depicts the intersection of the Gray dimensions of Professionalism versus Statutory Control and Uniformity versus Flexibility, dimensions associated with "Authority and Enforcement".

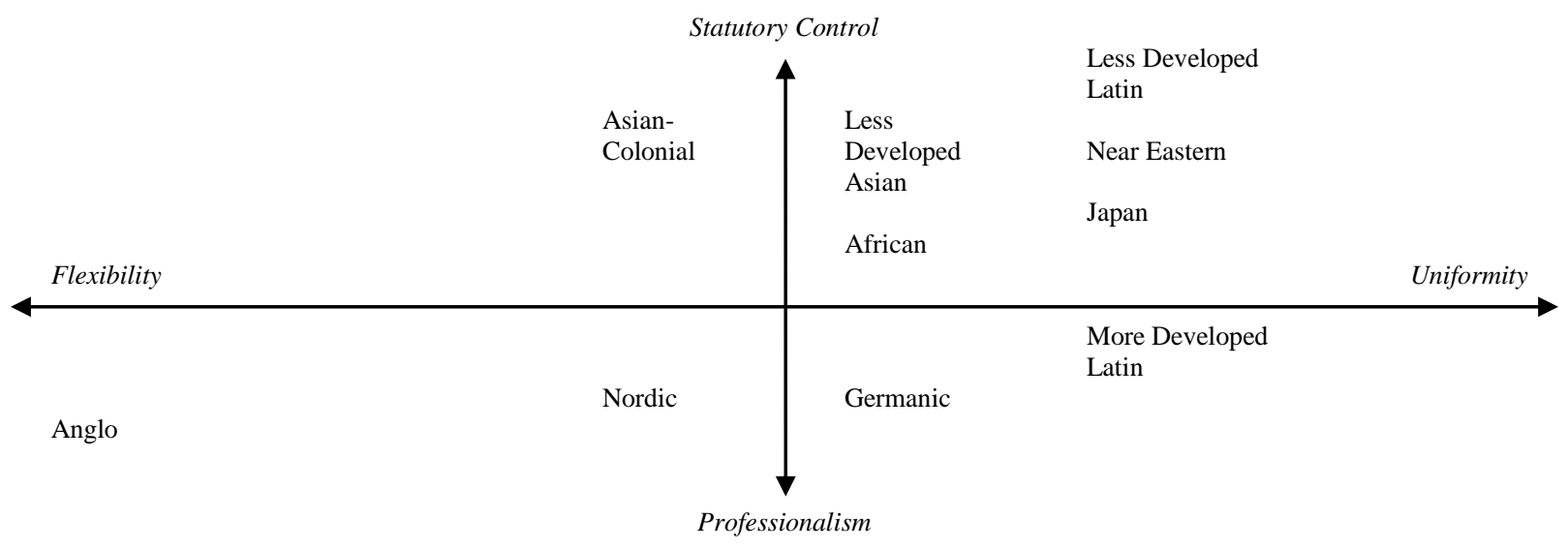

Figure 1: Accounting Systems - Authority And Enforcement

Figure 2 depicts the intersection of the Gray dimensions of Conservatism versus Optimism and Secrecy versus Transparency, dimensions associated with "Measurement and Disclosure" issues. The graphic positioning of the Anglo accounting group in each of these two figures indicates that the Anglo accounting group is seen by Gray to be closest of all the international accounting groups to the accounting value profile of Professionalism, Flexibility, Optimism and Transparency (Gray, 1988). 


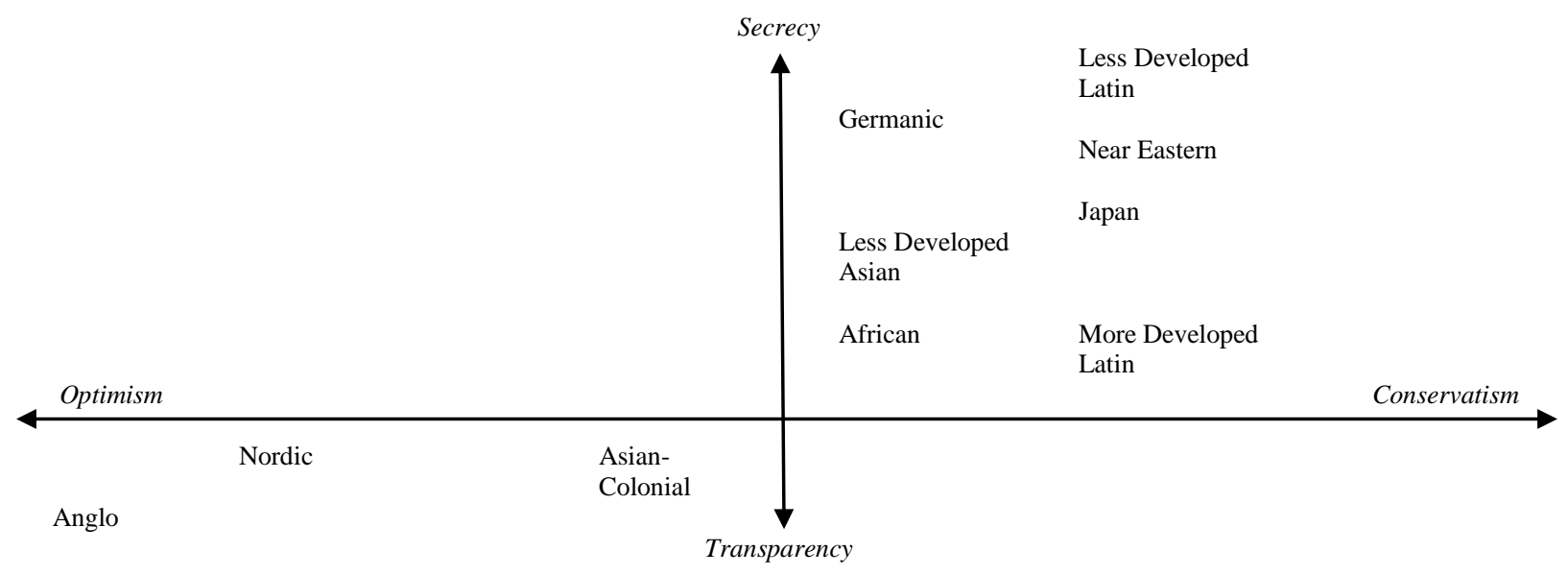

Figure 2: Accounting Systems - Measurement And Disclosure

\section{Examination of the Hofstede Six Dimensional Index for the Anglo-American Countries and the Conversion to Gray's Accounting Values}

The overall profile for the Anglo-American accounting group can be verified for the individual countries in this group by reviewing the indices attributed to these countries using the Hofstede four cultural dimensions and then converting this data to arrive at Gray accounting values for each country.

The Hofstede six-dimensional indices for each of the Anglo-American countries are summarized in Table 5 (Hofstede, Hofstede, \& Minkov, 2010).

Table 5: Hofstede Six Dimensional Indices For Anglo-American Accounting Tradition Countries

\begin{tabular}{|l|c|c|c|c|c|c|}
\hline $\begin{array}{c}\text { Anglo- } \\
\text { Accounting } \\
\text { Countries }\end{array}$ & $\begin{array}{c}\text { Power } \\
\text { Distance } \\
\text { PDI }\end{array}$ & $\begin{array}{c}\text { Individualism } \\
\text { IDV }\end{array}$ & $\begin{array}{c}\text { Masculinity } \\
\text { MAS }\end{array}$ & $\begin{array}{c}\text { Uncertainty } \\
\text { Avoidance } \\
\text { UAI }\end{array}$ & $\begin{array}{c}\text { Long-Term } \\
\text { Orientation } \\
\text { LTO }\end{array}$ & $\begin{array}{c}\text { Indulgence vs. } \\
\text { Restraint } \\
\text { IVR }\end{array}$ \\
\hline Australia & 36 & 90 & 61 & 51 & 21 & 71 \\
\hline Canada & 39 & 80 & 52 & 48 & 36 & \\
\hline New Zealand & 22 & 79 & 58 & 49 & 33 & \\
\hline United Kingdom & 35 & 89 & 66 & 35 & 51 & 75 \\
\hline United States & 40 & 91 & 62 & 46 & 26 & 6 \\
\hline
\end{tabular}

Hofstede's dimensional indices for these countries are extremely consistent, not only for the original four dimensions used by Gray in deriving his accounting value dimensions, but also for Hofstede's fifth and sixth cultural dimensions developed subsequently (Borker, 2012b). Table 5 summarizes all six of the Hofstede dimensional indices for the Anglo-American countries. South Africa has been excluded from the Anglo-American list due to issues regarding the differentiation of ethnic English versus ethnic Dutch data in the Hofstede survey (Hofstede, Hofstede, \& Minkov, 2010).

Conversion of the above Hofstede indices into Gray's four accounting value dimensions results in accounting value profiles for each of the countries listed in Table 5. These profiles are summarized by country in Table 6. The conversion clearly demonstrates the existence of a common accounting value profile for the AngloAmerican countries.

Table 6: Conversion Of Hofstede Data To Gray Accounting Value Dimensions

\begin{tabular}{|l|c|c|c|c|}
\hline $\begin{array}{c}\text { Anglo-Accounting } \\
\text { Countries }\end{array}$ & $\begin{array}{c}\text { Professionalism Versus } \\
\text { Statutory Control }\end{array}$ & $\begin{array}{c}\text { Uniformity Versus } \\
\text { Flexibility }\end{array}$ & $\begin{array}{c}\text { Conservatism Versus } \\
\text { Optimism }\end{array}$ & $\begin{array}{c}\text { Secrecy Versus } \\
\text { Transparency }\end{array}$ \\
\hline Australia & Professionalism & Flexibility & Optimism & Transparency \\
\hline Canada & Professionalism & Flexibility & Optimism & Transparency \\
\hline New Zealand & Professionalism & Flexibility & Optimism & Transparency \\
\hline United Kingdom & Professionalism & Flexibility & Optimism & Transparency \\
\hline United States & Professionalism & Flexibility & Optimism & Transparency \\
\hline
\end{tabular}




\section{EXPANSION OF THE GRAY HYPOTHESES TO INCLUDE THE HOFSTEDE FIFTH AND SIXTH DIMENSIONS}

Given the high degree of uniformity in the indices for all six Hofstede cultural dimensions for the AngloAmerican accounting group, it is proposed that Table 4 can be expanded to include the relationship between Gray's four accounting dimensions and Hofstede's fifth and six cultural dimensions. This expanded mapping is provided in Table 7.

Table 7: Expansion of Hofstede-Gray Relationships

\begin{tabular}{|l|c|c|c|c|c|c|}
\hline & $\begin{array}{c}\text { Power } \\
\text { Distance: } \\
\text { PDI }\end{array}$ & $\begin{array}{c}\text { Individualism: } \\
\text { IDV }\end{array}$ & $\begin{array}{c}\text { Masculinity: } \\
\text { MAS }\end{array}$ & $\begin{array}{c}\text { Uncertainty } \\
\text { Avoidance: } \\
\text { UAI }\end{array}$ & $\begin{array}{c}\text { Long-Term } \\
\text { Orientation: } \\
\text { LTO }\end{array}$ & $\begin{array}{c}\text { Indulgence vs. } \\
\text { Restraint: } \\
\text { IVR }\end{array}$ \\
\hline Conservatism & + & - & - & ++ & + & - \\
\hline Uniformity & + & -- & $?$ & ++ & + & - \\
\hline Professionalism & - & ++ & $?$ & -- & - & + \\
\hline Secrecy & ++ & -- & - & ++ & + & - \\
\hline
\end{tabular}

In the absence of any compelling arguments to the contrary, it can be assumed that the direct and inverse relationships between Hofstede's LTO and IVR dimensions and each of Gray's four accounting value dimensions mapped above are normal linkages. In Anglo-American accounting cultures, it is not difficult to see how a low LTO and IVR complement the Anglo-American accounting profile. Low LTO fits well with offering clear short-term financial results with disclosure immediately available for investor decision-making. In addition, high IVR complements the notion of the freedom of judgment associated with professionalism and the related values of flexibility and optimism.

\section{THE CASE FOR THE ANGLO-AMERICAN VALUE PROFILE AS THE IFRS-FAVORABLE PROFILE}

All of Anglo-American countries are societies with strong democratic values and a long standing tradition of publically traded stock companies. All these countries support financial reporting that emphasizes the information needs of equity and other investors in the capital markets. This is in sharp contrast to countries where financing has traditionally been associated with large banks or state funding. The accounting standard setting bodies in the Anglo-American countries are generally independent organizations of professional accountants and even in Australia, where the Australian Accounting Standards Board (AASB) is part of the national government, there is broad acceptance of the public accountant's independence of judgment on professional matters (Borker, 2012c).

The concepts and history of IFRS, and the organization and procedures of the standard setting body the IASB, reflect a strong connection with the Anglo-American accounting culture. IFRS has strong similarities to US and UK GAAP. Historically, the IASB has been based in New York City and now in London. In 1983, the former International Accounting Standards Committee (IASC) was reorganized into the current International Accounting Standards Board (IASB). That was also the same year that the US GAAP's standard setting body, formerly the Accounting Principles Board (APB), was reorganized as the Financial Accounting Standards Board (FASB). The similarity of the acronyms is hardly accidental. It has been noted that the development and standard setting of both the IASB and the FASB have been significantly influenced by the major international accounting firms, including PricewaterhouseCoopers, Ernst\&Young, Deloite, KPMG and the former Arthur Andersen, both directly and through the backgrounds of their members (Botzem, 2012). Under FASB, US GAAP has been heavily oriented toward the information needs of modern capital markets to facilitate the effective allocation of market capital resources by providing what FASB refers to in its "Statements of Concepts" as user information for decision making. US GAAP is extensively detailed and documented to the extent that it is often referred to as rule driven, although many would agree that its rules are generally principle based. IFRS concepts share a focus on meeting the informational decision making needs of the modern capital markets, but also emphasize the concept of corporate accountability (previously stewardship) which is more prominent in UK GAAP. IFRS has a smaller body of work than does US GAAP and has been described as more principles-driven than US GAAP (Benson, Bromwich, \& Wagenhofer, 2006). The principles based orientation of IFRS is viewed as making it capable of being more adaptive to the special local needs of communities around the world (Botzem, 2012; Carmona \& Tombetta, 2008). 
Despite differences in the Anglo-American accounting world, it appears that, based on the central role of Anglo-American accounting in the evolution and proliferation of IFRS, one can propose the Anglo-American profile as the basis for an optimal profile, in terms of Gray accounting values, for the development of IFRS type accounting systems. This IFRS-favorable profile is summarized in Table 8 (Borker, 2012a and 2012b).

Table 8: IFRS-favorable Profile Based On Gray's Four Original Values Dimensions

\begin{tabular}{|l|l|}
\hline Gray Accounting Dimensions & IFRS-favorable Profile \\
\hline Professionalism vs. Statutory Control & Professionalism \\
\hline Uniformity versus Flexibility & Flexibility \\
\hline Conservatism versus Optimism & Optimism ${ }^{1}$ \\
\hline Secrecy versus Transparency & Transparency \\
\hline
\end{tabular}

This IFRS-favorable profile provides a useful point of reference/diagnostic tool in determining results from the analyses of individual countries or groupings.

\section{DISCUSSION}

The IFRS-favorable profile can be used as a base-line for assessing opportunities and challenges faced by individual countries in adoption/convergence with IFRS and subsequent evolution of IFRS in the accounting culture. The more a particular country's accounting value profile is at variance with the IFRS-favorable profile, the greater the exposure to subtle cultural forces that may present a challenge to successful adoption and evolution with IFRS in that country.

An example of such maximal variance is Russia, many of its former republics, and certain Central and East European countries. The Russian indices for the Hofstede six cultural dimensions are the exact opposite of those characterizing the Anglo-American accounting group, as seen in Table 9. Here the Russian indices are juxtaposed to the values for the Anglo-Accounting countries in Table 5 (Hofstede, Hofstede \& Minkov, 2010; Borker, 2012a).

Table 9: Russia's Indices For Hofstede Six Cultural Dimensions Juxtaposed

\begin{tabular}{|l|c|c|c|c|c|c|}
\hline $\begin{array}{c}\text { Anglo-American } \\
\text { Accounting } \\
\text { Countries }\end{array}$ & $\begin{array}{c}\text { Power } \\
\text { Distance } \\
\text { PDI }\end{array}$ & $\begin{array}{c}\text { Individualism } \\
\text { IDV }\end{array}$ & $\begin{array}{c}\text { Masculinity } \\
\text { MAS }\end{array}$ & $\begin{array}{c}\text { Uncertainty } \\
\text { Avoidance } \\
\text { UAI }\end{array}$ & $\begin{array}{c}\text { Long-Term } \\
\text { Orientation } \\
\text { LTO }\end{array}$ & $\begin{array}{c}\text { Indulgence vs. } \\
\text { Restraint } \\
\text { IVR }\end{array}$ \\
\hline Australia & 36 & 90 & 61 & 51 & 21 & 71 \\
\hline Canada & 39 & 80 & 52 & 48 & 36 & 68 \\
\hline New Zealand & 22 & 79 & 58 & 49 & 33 & 75 \\
\hline United Kingdom & 35 & 89 & 66 & 35 & 51 & 69 \\
\hline United States & 40 & 91 & 62 & 46 & 26 & 68 \\
\hline RUSSIA & 93 & 39 & 36 & 95 & 81 & 20 \\
\hline
\end{tabular}

Hofstede's indices for Russia are at the opposite end from those of the Anglo-American countries. Consequently, Russia's Gray derived accounting value profile is also at the extreme opposite, as shown in Table 10.

Table 10: Russia's Gray Derived Accounting Value Profile Juxtaposed To The Profile Of Anglo-American Accounting Countries

\begin{tabular}{|l|c|c|c|c|}
\hline \multicolumn{1}{|c|}{$\begin{array}{c}\text { Anglo-American } \\
\text { Accounting Countries }\end{array}$} & $\begin{array}{c}\text { Professionalism Versus } \\
\text { Statutory Control }\end{array}$ & $\begin{array}{c}\text { Uniformity Versus } \\
\text { Flexibility }\end{array}$ & $\begin{array}{c}\text { Conservatism Versus } \\
\text { Optimism }\end{array}$ & $\begin{array}{c}\text { Secrecy Versus } \\
\text { Transparency }\end{array}$ \\
\hline Australia & Professionalism & Flexibility & Optimism & Transparency \\
\hline Canada & Professionalism & Flexibility & Optimism & Transparency \\
\hline New Zealand & Professionalism & Flexibility & Optimism & Transparency \\
\hline United Kingdom & Professionalism & Flexibility & Optimism & Transparency \\
\hline United States & Professionalism & Flexibility & Optimism & Transparency \\
\hline RUSSIA & Statutory Control & Uniformity & Conservatism & Secrecy \\
\hline
\end{tabular}

\footnotetext{
${ }^{1}$ Although Conservatism is, on some level, basic to all accounting systems, Optimism is assumed to reflect a greater openness to new ways of measuring and evaluating, such as fair value accounting. This is seen as characteristic of the openness to change and evolution of standards in IFRS and US GAAP. The attitudes of accountants in the US and UK are much less conservative than those in France and Germany (Gray, 1988).
} 
Russia's maximum variance to the IFRS-favorable profile certainly does not mean that Russia is unlikely to adopt IFRS. If fact, Russia and many other nations with same or similar accounting value profiles, are fully aware of the economic and political importance of IFRS. Based on Gray accounting values, Russia may have been unlikely to have evolved an IFRS like accounting system in isolation. However, the need to compete in the global market place, including the global capital markets that determine the allocation of resources to countries, companies and projects through the world, compels Russia to pursue IFRS accounting reform, in spite of its possible contrary cultural orientation. Russia has been delayed in its adoption time-table by slowness of the Russian Duma to approve the necessary laws - Russia being a very statutory control oriented country. Nevertheless, Russia has adopted IFRS and requires that all consolidated stock companies prepare their financial reports and be audited in accordance with IFRS for fiscal 2012 (Borker, 2012c).

In the case of Russia, how is awareness of the extreme variance between Russia's accounting value profile and the IFRS-favorable profile useful? The answer would seem to be that the variance serves as a diagnostic tool to warn us that Russia may still experience cultural "bumps in the road" in spite of its well-motivated commitment to IFRS. This may lead to consideration of various actions that may minimize cultural resistance or distortion, e.g. improvements in accounting education, upgrading of accounting and audit professionals, better informing the general public, and others.

It should not be assumed that countries with little or no variance with the IFRS-favorable profile are more likely to be the first to fully adopt IFRS, or that those with the greatest variance will be the last to adopt IFRS. Even though the FASB and IASB have worked jointly on most new accounting issues since 2002 and the US SEC has issued several "roadmaps" for a US GAAP convergence with IFRS in the next few years, factors such as large country size of the US, national and professional pride, and the high cost of achieving full convergence with IFRS still make it difficult to predict when the FASB will achieve full convergence with IFRS (Hail, Leuz \& Wysocki, 2009). On the other hand, many countries with less cultural affinity or infrastructure for IFRS, such as Greece, have immediately adopted IFRS because of the EU mandate (Karampinis \& Hevas, 2011). In the long run, it is assumed that the United States and other countries with low or no variances to the IFRS-favorable profile, will have an easier time using and adapting to IFRS, while countries in the other category, may face special challenges over time.

\section{CONCLUSION}

This paper demonstrates that the relationships between the Gray accounting value constructs and the Hofstede original four cultural dimensions can be expanded to include Hofstede's fifth and sixth cultural dimensions. Further, it shows the high degree of commonality of the Anglo-American countries, both in terms of Hofstede's six cultural dimensions and as a distinct accounting culture sharing a common accounting value profile in terms of the Gray model. Finally, based on the history, origins, and concepts of IFRS, the paper proposes an IFRS-favorable profile identical to the Anglo-American accounting profile based on the Gray accounting values, and justifies the need for such a profile based on its potential as a diagnostic tool in addressing opportunities to enhance the success of IFRS adoption and implementation in various accounting cultures. As already mentioned, the amount of variance of a country's accounting value profile with the IFRS-favorable profile is not a predictor of the speed or ultimate success of IFRS adoption or implementation. Gray never intended his accounting values to be anything more than one set of cultural factors, which, in the absence of other internal or external influences, might incline a country to evolve a certain type of accounting system. Clearly, in the current interconnected and interdependent global, economic and political environment, the idea of an underlying, cultural accounting values orientation represents but one of a variety of competing factors influencing the adoption of IFRS. Being mindful of such cultural values can provide useful feedback for efforts to enhance the implementation of IFRS through a variety of approaches, including education, professional upgrades, institutional infrastructure reform, and others means.

There are several areas of future research and inquiry that could follow the current study. One area of interest would be to refine the functional relationship between the Hofstede fifth and sixth dimensions in Gray's model and to test their usefulness in actual empirical studies. Also, since there is a possibility of additional cultural dimensions arising from the work of Hofstede's coauthor Minkov and others, it will be useful to test the relationship of these new cultural dimensions to Gray's current accounting value dimensions (Minkov 2011, 2012). Another area of interest is the application of other cultural value research, such as data from World Values Survey, to the 
Gray accounting value concepts, as has been initially investigated in one recent study (Bogdan \& Stefana-Maria, 2009; European_Value_Studies_Group \& World_Values_Survey_Association, 2006; Minkov, 2012). Ultimately, the expansion of our focus to additional cultural data may well lead to an expansion of Gray's four accounting value dimensions to include new accounting dimensions or sub-dimensions. Such new dimensions might capture differences within one accounting culture, such as, for example, the split within the Anglo-American accounting culture on the relative importance of accountability and stewardship versus informing investors for efficient allocation of capital resources. Finally, given the multiple competing factors that influence the development and success of accounting change, it would be useful to develop a methodology for weighting accounting culture variables and other factors in order to better explain the past and anticipate future developments.

\section{AUTHOR INFORMATION}

David Borker holds a Ph.D. from Yale, Master of Accounting/MBA from Ohio State University and A.B. from Cornell. Dr. Borker is well suited for research in international accounting and business. A native speaker of English, he is fluent in Russian, German and Czech and uses numerous other languages in his research. Dr. Borker has extensive experience as an academic, consultant and a businessman working in Russia, Eastern Europe and the CIS. He teaches accounting, management and international business at Manhattanville College and is a licensed CPA. E-mail: David.Borker@mville.edu

\section{REFERENCES}

1. Baydoun, N., \& Willet, R. (1995). Cultural Relevance of Western Accounting Systems to Developing Countries. ABACUS, 31(1), 67-92.

2. Benson, G. J., Bromwich, M., \& Wagenhofer, A. (2006). Principles- Versus Rules-based Accounting Standards: The FASB's Standard Setting Strategy. Abacus, 42(2), 165-188.

3. Bogdan, D., \& Stefana-Maria, C. (2009). A Discussion on New Cultural Transformations. Transformations Monétaires et Financières dans les Pays d'Europe Centrale et Orientale, 11, pp. 103-129.

4. Borker, D. R. (2012a). Accounting, Culture and Emerging Economies: IFRS in The BRIC Countries. Journal of Business and Economics Research, 10(5), 313-324.

5. Borker, D. R. (2012b). Accounting, Culture and Emerging Economies: IFRS in Central and Eastern Europe. International Business \& Economics Research Journal, 11(9), 1003-1017.

6. Borker, D. R. (2012c). Stepped-Up Progress on IFRS in Russia: History in The Making. International Business and Economics Research Journal, 11(2), 255-268.

7. Botzem, S. (2012). The Politics of Accounting Regulation: Organizing Transnational Standard Setting in Financial Reporting. Northhampton, Mass: Edward Elgar Publishing.

8. Carmona, S., \& Tombetta, M. (2008). On the Global Acceptance of IAS/IFRS Accounting Standards: The Logic and Implications of the Principles-based System. Journal of Accounting and Public Policy, 27(6), 456-461.

9. Chanchani, S., \& MacGregor, S. (1999). A Synthesis of Cultural Studies in Accounting. Journal of Accounting, 18, 1-30.

10. European_Value_Studies_Group, \& World_Values_Survey_Association. (2006). European and World Values Surveys Four-Wave Integrated Data File 1981-2004.

11. Gray, S. J. (1988). Towards a Theory of Cultural Influence on the Development of Accounting Systems Internationally. Abacus, 24(1), 9-11, 12.

12. Hail, L., Leuz, C., \& Wysocki, P. D. (2009, February 25). Global Accounting Convergence and the Potential Adoption of IFRS by the United States: An Analysis of Economic and Policy Factors. (I. Social Science Electronic Publishing, Ed.) Retrieved from Social Science Researech Network: http://ssrn.com/abstract=1357331 or http://dx.doi.org/10.2139/ssrn.1357331

13. Hofstede, G. (1980). Cultures Consequences: International Differences in Work Related Values. Newbury Park, NJ: Sage. 
14. Hofstede, G., Hofstede, G. J., \& Minkov, M. (2010). Cultures and Organizations: Software of the Mind: Intercultural Cooperation and its Importance for Survival. New York: McGrawHill.

15. Karampinis, N. I., \& Hevas, D. L. (2011). Mandating IFRS in an Unfavorable Environment: The Greek Experience. The International Journal of Accounting, 46(2), 304-332.

16. Minkov, M. (2011). Cultural Differences in a Globalizing World. Bingley, U.K.: Emerald Group.

17. Minkov, M. (2012). Cross-Cultural Analysis: The Science and Art of Comparing the World's Modern Societies and their Cultures. London: Sage.

18. Mueller, G. G. (1967). International Accounting. Macmillan.

19. Nair, R. D., \& Frank, W. G. (1980). 'The Impact of Disclosure and Measurement Practices on International Accounting Classifications. The Accounting Review, 55(3), 426-450.

20. Nobes, C. W. (1983). A Judgemental Classification of Financial Reporting Practices. Journal of Business Finance and Accounting, 10(1), 1-19.

21. Radebaugh, L. H. (1975). 'Environmental Factors Influencing the Development of Accounting Objectives, Standards and Practices in Peru. International Journal of Accounting Education and Research, 11(1), 3956.

22. Zeff, S. A. (1971). Forging Accounting Principles in Five Countries: A History of Trends. Stipes. 
NOTES 